\title{
Palynostratigraphy of Permian succession in the Mand-Raigarh Coalfield, Chhattisgarh, India and phytogeographical provincialism
}

\author{
Srikanta Murthy*, Ram-Awatar and Saurabh Gautam \\ Birbal Sahni Institute of Palaeobotany, 53 University Road, Lucknow 226 007, India. \\ *Corresponding author.e-mail: Srikanta_murthy22@rediffmail.com
}

\begin{abstract}
Palynofloras have been recorded from the Barakar Formation in the Borehole MBKW-3, BarpaliKarmitikra Block, Mand-Raigarh Coalfield, Chhattisgarh. Three distinct palynoassemblages have been identified and referred to the following palynoassemblage zones - Gondisporites raniganjensis (Latest Permian); Faunipollenites varius (latest Early Permian), and Scheuringipollenites barakarensis (late Early Permian). It is inferred that these deposits contain the representative palynoassamblages of Early to Late Permian in age. The First Appearance Datum (FAD)s of Arcuatipollenites pellucidus, A. ovatus, Guttulapollenites hannonicus, Lundbladispora microconata, Alisporites opii, Klausipollenites sp., and Goubinispora indica (at 41.95, 45.90, $98.35 \mathrm{~m}$ depths), indicate the closing phase of Permian, as these elements are the key species that mark a transition from Permian to the Lower Triassic. An attempt has been made here to reconstruct the phytogeographical provincialism on the basis of Guttulapollenites recorded in this basin.
\end{abstract}

\section{Introduction}

The Mand-Raigarh Coalfield is located in the central part of the Upper Mahanadi Gondwana Master Basin (figure 1) and extends over a vast stretch from Sambalpur district of Orissa in the southeast, to the Surguja district of Chhattisgarh in the northwest. The Gondwana sediments here have been subdivided into different coalfields, e.g., IbRiver, Mand-Raigarh, Korba and Hasdo-Arand. The state boundary between Chhattisgarh and Orissa is generally considered to mark the southeastern limit of Mand-Raigarh Coalfield. This coalfield actually covers the areal extents of three initially assigned coalfields, the North Raigarh, South Raigarh, and Mand River coalfields (Raja Rao 1983). Later, on the basis of tectonic and lithostratigraphic modelling, Chakraborti (2001) revised the geology of Mand Coalfield.
The north and western parts of the MandRaigarh Coalfield have been referred to Mand subbasin. It is separated from the Raigarh and Ib river basin in the east by a N-S to NNE-SSW trending lineament passing the Konkori-GersaSirsinga area. On the west, it is separated from the Korba-Basin by the NW-SE trending MauhariMachida lineament, and from the Hasdo-Arand Basin in the north by the well defined E-W trending Dhirpada-Kedma-Chornai shear zone. Within these structural boundaries, the Mand sub-basin acquired NNW-SSE to NW-SE trending asymmetrical shape, with an aerial extent of about $2000 \mathrm{~km}^{2}$. The area is bounded by latitudes $22^{\circ} 05^{\prime} 00^{\prime \prime}-22^{\circ} 47^{\prime} 00^{\prime \prime} \mathrm{N}$ and longitudes $82^{\circ} 55^{\prime} 00^{\prime \prime}-$ $83^{\circ} 15^{\prime} 00^{\prime \prime} \mathrm{E}$ (figure 2).

Palaeobotanical data from this coalfield are meagre and scattered. Though different species of Glossopteris, Schizoneura, Vertebraria and

Keywords. Palynology; Permian; phytogeography; Mand-Raigarh Coalfield. 


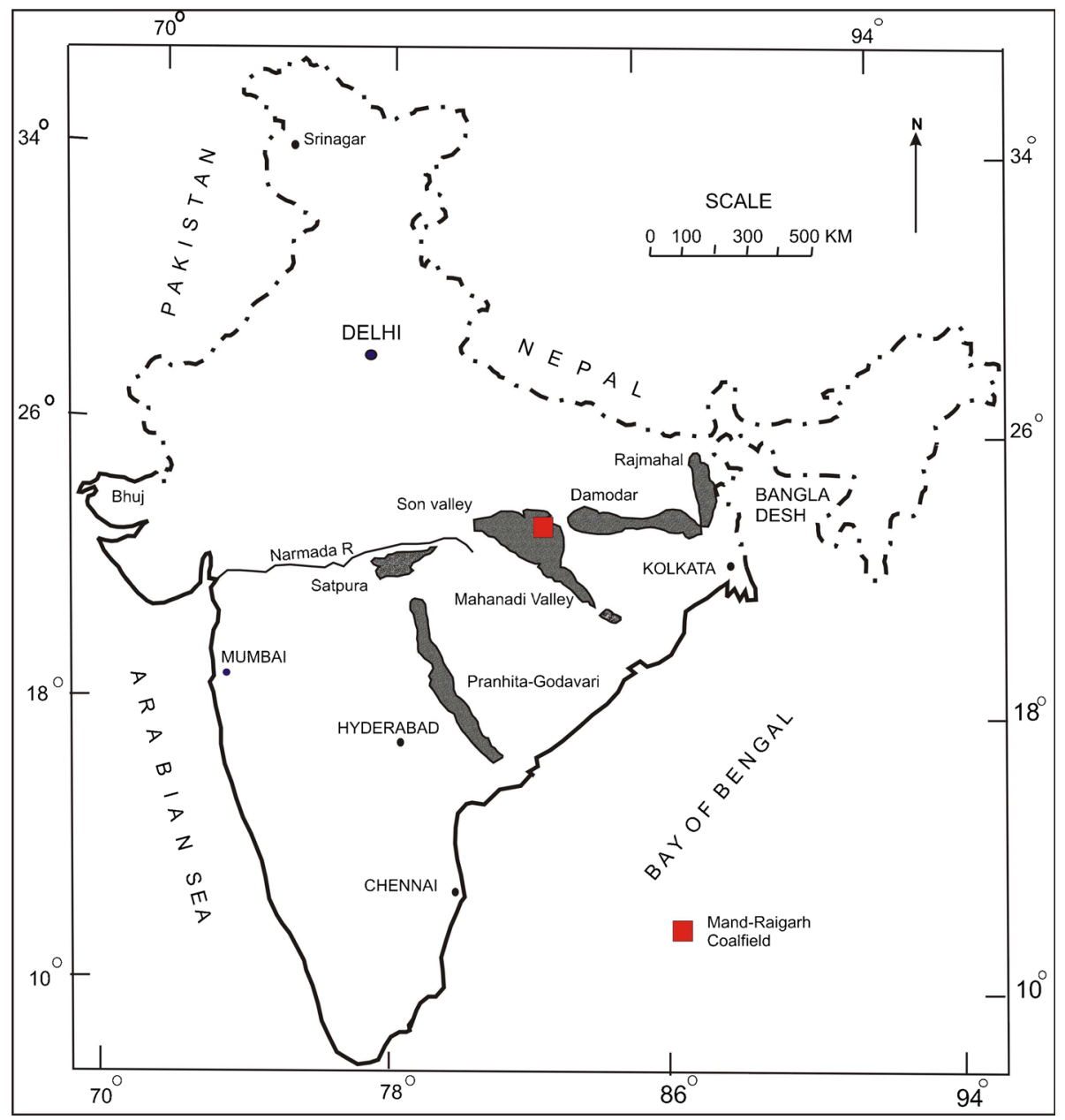

Figure 1. Map showing the study area and principal Gondwana basins of India.

Phyllotheca have been recorded by Raja Rao (1983), Chakraborti and Chakraborty (2001) have recorded Early and Middle Triassic plant megafossils from the Kamthi Formation. They also reported Alisporites, Falcisporites, Klausipollenites and Weylandites from the Kamthi Formation, near the Baronakund area, Raigarh Coalfield, Chhatisgarh. In addition, Jana et al. (2002), Ram-Awatar (2007) and Chakraborti and Ram-Awatar (2006) have also recorded Early-Late Permian palynoflora from this coalfield. In the present investigation, Early and Late Permian palynofossils have been recorded from subsurface (MBKW-3) samples which have an important bearing on the correlation of coal seams in the area.

\section{General geology}

The Gondwana sediments of the Mand-Raigarh Coalfield are classified into the Talchir, Barakar, and Kamthi formations. The geology of the MandRaigarh Basin has undergone a major change when regional exploration and large scale mapping was carried out over a large part of the basin by Chakraborti et al. (2002). On the basis of lithological attributes, the total sedimentary package of the basin has been recategorized into Talchir, Barakar, Barren Measures, Raniganj, and Kamthi formations.

In the Mand Basin, Gondwana sediments are juxtaposed with quartzites of the Chandrapur Group (Chhattisgarh Supergroup) in the southwest, and metamorphic rocks of Raigarh-Sundargarh schist belt in the northwest. The contact between the Gondwana strata and the metamorphics is faulted in nature. The general stratigraphic succession in the Mand-Raigarh Coalfield is shown in table 1.

\section{Materials and methods}

The samples for the present study were collected from borecore MBKW-3, located in the exploration blocks of Barpali-Karmitikra, in the northwestern part of the Mand Basin (figures 2 and 3). A total of 83 samples of varied lithofacies, comprising 
Table 1. Generalized lithostratigraphy of the Mand-Raigarh Coalfield, Chhattisgarh (after Chakraborti et al. 2002).

\begin{tabular}{|c|c|c|c|c|}
\hline Age & \multicolumn{2}{|c|}{ Formation } & Thickness & Lithology \\
\hline $\begin{array}{l}\text { Recent to sub- } \\
\text { Recent }\end{array}$ & & & & Alluvial soil, pebbly to bouldery bed with silty clay band, laterite, etc. \\
\hline Cretaceous & \multicolumn{2}{|c|}{ Deccan Trap } & $200 \mathrm{~m}+$ & Basaltic and doleritic flows, dykes and sills. \\
\hline $\begin{array}{l}\text { Lower to } \\
\text { Middle Triassic }\end{array}$ & \multicolumn{2}{|c|}{$\begin{array}{l}\text { Supra-Panchet/ } \\
\text { Kamthi } \\
\text { Formation }\end{array}$} & $280 \mathrm{~m}+$ & $\begin{array}{l}\text { Buff coloured, coarse to pebbly, cross bedded, reworked shaly clasts } \\
\text { bearing sandstone with abundant ferruginous sandstone bands } \\
\text { with/without red claystone to siltstone or white marl bed at the base. }\end{array}$ \\
\hline \multirow{5}{*}{$\begin{array}{l}\text { Upper Permian } \\
\text { to } \\
\text { Lower Permian }\end{array}$} & \multicolumn{2}{|c|}{$\begin{array}{l}\text { Raniganj } \\
\text { Formation }\end{array}$} & $180-250 \mathrm{~m}$ & $\begin{array}{l}\text { Cyclic sequence of fine to medium grained sandstone, grey shale, } \\
\text { claystone, carbonaceous shale and two coal seams. }\end{array}$ \\
\hline & \multicolumn{2}{|c|}{ Barren Measures } & $280-350 \mathrm{~m}$ & $\begin{array}{l}\text { Interbeded sequence of sideritic claystone, grey shale, siltstone and fine grained } \\
\text { sandstone; carbonaceous shale and some medium grained sandstone bands in the } \\
\text { east to dominantly medium to coarse grained sandstone with interbanded } \\
\text { sequence of sideritic claystone, grey shale, siltstone and fine grained sandstone; } \\
\text { carbonaceous shale and light green siltstone to sandstone bands. }\end{array}$ \\
\hline & \multirow{3}{*}{ 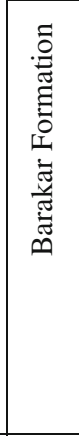 } & Upper & $180-220 \mathrm{~m}$ & $\begin{array}{l}\text { Mostly medium to coarse grained sandstone with subordinate very coarse to } \\
\text { pebbly massive arkosic sandstone. This fining upward sequence includes } \\
\text { five regional coal seams (No. V to IX) and one local coal seam (No. VIIL). } \\
\text { Grey claystone to siltstone bands are common at the top and bottom. }\end{array}$ \\
\hline & & Middle & $140-200 \mathrm{~m}$ & $\begin{array}{l}\text { Mostly coarse to very coarse grained sandstone with granule to pebbly sandstone } \\
\text { at the base of each depositional sequence. Fine grained sandstone and siltstone } \\
\text { are rarely present. It contains five to six local seams (Nos./ bands IVL1 TO IVL6). }\end{array}$ \\
\hline & & Lower & $280-400 \mathrm{~m}$ & $\begin{array}{l}\text { Mostly very coarse grained to granule sized arkosic sandstone with pink quartz } \\
\text { and garnet grains and also with subordinate medium to coarse grained sandstone. } \\
\text { It includes four regional coal seams (No. I - IV). Pebbly to matrix-based } \\
\text { conglomerate bands are common. Basal } 40-50 \mathrm{~m} \text { zone is fine to medium grained } \\
\text { with minor siltstone. }\end{array}$ \\
\hline $\begin{array}{l}\text { Lower most } \\
\text { Permian to Upper } \\
\text { Carboniferous }\end{array}$ & \multicolumn{2}{|c|}{$\begin{array}{l}\text { Talchir } \\
\text { Formation }\end{array}$} & $150 \mathrm{~m}+$ & $\begin{array}{l}\text { Khaki to brownish green, siltstone, shale and fine grained sandstone with } \\
\text { two boulder beds. }\end{array}$ \\
\hline Late Proterozoic & \multicolumn{2}{|c|}{$\begin{array}{l}\text { Chandrapur } \\
\text { Group }\end{array}$} & & Variegated quartzose sandstone, calcareous, variegated shale. \\
\hline \multicolumn{5}{|c|}{ - } \\
\hline Early Proterozoic & \multicolumn{2}{|c|}{$\begin{array}{l}\text { Bilaspur, } \\
\text { Raigarh, } \\
\text { Sundargarh } \\
\text { Complex. }\end{array}$} & & Vein quartz, pegmatite, granite gneiss, massive granite, etc. \\
\hline
\end{tabular}

mudstones, silty shales, shales, coaly shales and coal horizons from the borecore MBKW-3 (41.95$640.00 \mathrm{~m}$ depth) were processed for spore-pollen study. Only 75 samples have yielded rich and diverse palynotaxa. For palynological preparations, $50 \mathrm{gm}$ of sediments were crushed and treated with $40 \%$ hydrofluoric acid for 3-4 days to remove silica. This was followed by treatment with nitric acid for 5 days to digest the organic matter. The residue was treated with $10 \%$ potassium hydroxide to release the humus. After thorough wash with distilled water, the residues were mixed with polyvinyl alcohol, smeared over cover glasses and kept to dry at room temperature. After complete drying, the cover glasses were fixed to slides with Canada balsam. Five slides were prepared for each sample.
Microscopic observation (Olympus BX61model) was done at species level for microfloral analysis.

\section{Palynological observations}

The preservation of the palynomorphs is variable within the samples. Recovery is frequently very good, can be low to moderate. Specimens are yellowish-dark brown in colour, distorted, and broken to fairly well-preserved (Plates I and II; table 2). The relative occurrences of the taxa vary from rare $(<1 \%)$, common $(1-5 \%)$, fair $(5-10 \%)$ to an abundance $(11-25 \%)$ and dominant $(>25 \%)$ in an assemblage, and based on changes in the palynomorphs of characteristic genera and species 




Figure 2. Geological map of Mand-Raigarh Coalfield showing location of borehole MBKW-3.

(tables 3 and 4), three palynoassemblage zones were identified in the $598.05 \mathrm{~m}$ thick strata of Permian successions of borecore MBKW-3. The species identified herein are listed in table 5 .

\subsection{Palynoassemblage-I; Depth 41.95-98.35 m (table 4)}

Dominant: Striatopodocarpites

Subdominant: Gondisporites

The assemblage recovered from the shales, carbonaceous shales, and coal in 242.94-m thick strata is characterised by a dominance of Striatopodocarpites and Gondisporites, along with fair occurrence of Faunipollenites spp., Guttulapollenites hannonicus, Arcuatipollenitess spp., Lundbladispora micorconata, Goubinispora indica, Alisporites opii and Klausipollenites spp. Some palynomorphs, such as, Microbaculispora, Microfoveolatispora, Crescentipollenites, Weylandites, Distriatites, Didecitriletes and Scheuringipollenites are rare in occurrence. The FADs of Arcuatipollenites pellucidus, Guttulapollenites hannonicus, Lundbladispora microconata and Klausipollenites sp. at $41.95 \mathrm{~m}$ are significant, 
BH.MBKW-3

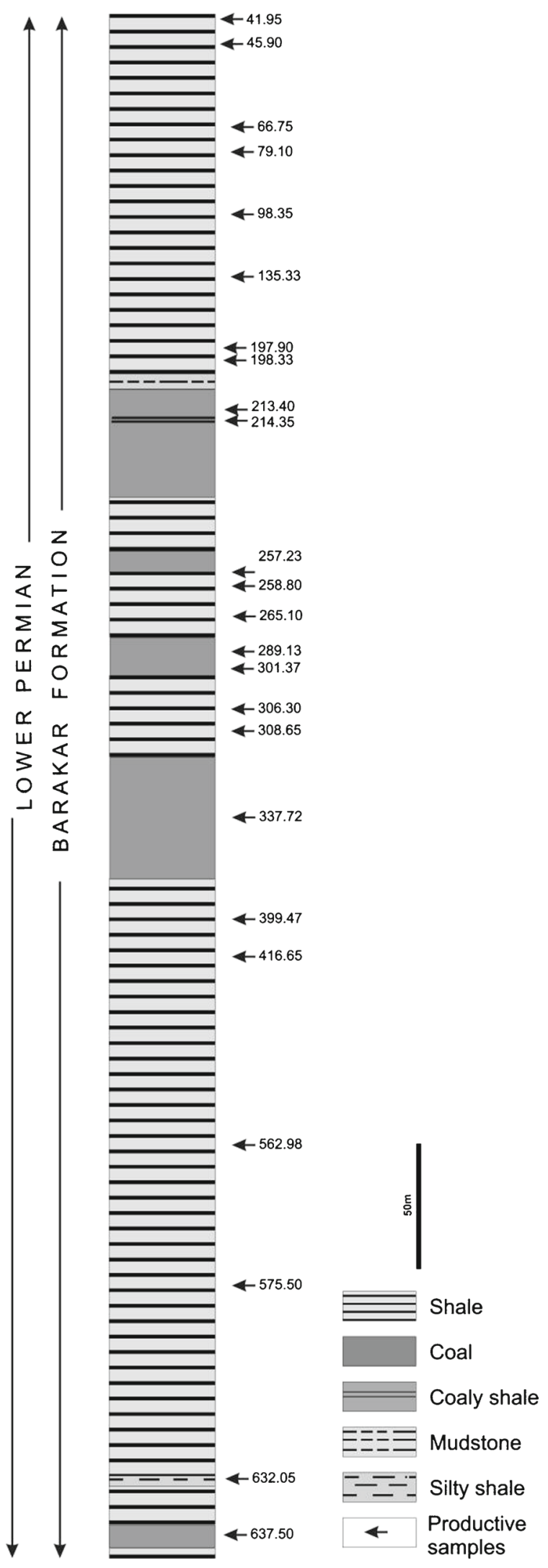

Figure 3. Lithologic column of borehole MBKW-3, MandRaigarh Coalfield showing individual lithofacies, and location of productive samples in the succession. because they represent the terminal phase of Late Permian sedimentation on the Indian peninsula (Vijaya and Tiwari 1987; Tiwari and Tripathi 1992).

This composition of palynoassemblage- 1 is very similar to the known palynoflora from the upper part of the Raniganj Formation in Damodar Basin in having an abundance of Gondisporites, Striatopodocarpites, and Faunipollenites. Hence, palynoassemblage-I is placed in the Gondisporites raniganjensis assemblage zone of Tiwari and Tripathi (1992), dated as Late Permian in age.

Palynodating: Late Permian (Raniganj Formation).

\subsection{Palynoassemblage-II; Depth 135.55-284.89 m (table 4)}

\section{Dominance: Faunipollenites}

Subdominance: Scheuringipollenites

Palynomorphs were recovered from mudstones, micaceous siltstones, shales, coaly shales and coal horizons in 149.34-m thick strata of the Barakar Formation. The striate bisaccate pollen grain Faunipollenites was dominant in the assemblage, while nonstriate bisaccate pollen, e.g., Scheuringipollenites was subdominant in this assemblage zone. Moderate to low occurrence of striate bisaccate palynomorphs like Verticipollenites, Rhizomaspora, Dicappipollenites, Platysaccus, Striasulcites, Tiwariasporis, Weylandites, Parasaccites, Striamonosaccites sp., Guttulapollenites sp., Barakarites sp., Potonieisporites sp., and nonstriate bisaccates is also recorded. Trilete spores are infrequent but are represented by Microfeveolatispora, Microbaculispora, Brevitriletes and Horriditriletes.

Palynoassemblage-II correlates with the generic acme-zone of the Faunipollenites-Scheuringipollenites zone in the Barakar Formation of the Damodar Basin which is late Early Permian in age (Tiwari and Tripathi 1988, 1992).

Palynodating: Late Early Permian (Upper Barakar Formation).

\subsection{Palynoassemblage-III; Depth 287.15-640.00 m (table 4)}

Dominant: Scheuringipollenites

Subdominant: Faunipollenites

The siltstones, shales, coaly shales, and coal horizons of the Barakar Formation yielded abundant and qualitatively diversified spore-pollen assemblages. Nonstriate bisaccate pollen taxon Scheuringipollenites was most abundant, followed by Faunipollenites spp., Striatopodocarpites and Horriditriletes palynotaxa recorded between the depths 287.15-337.72 m. Less common monosaccate 

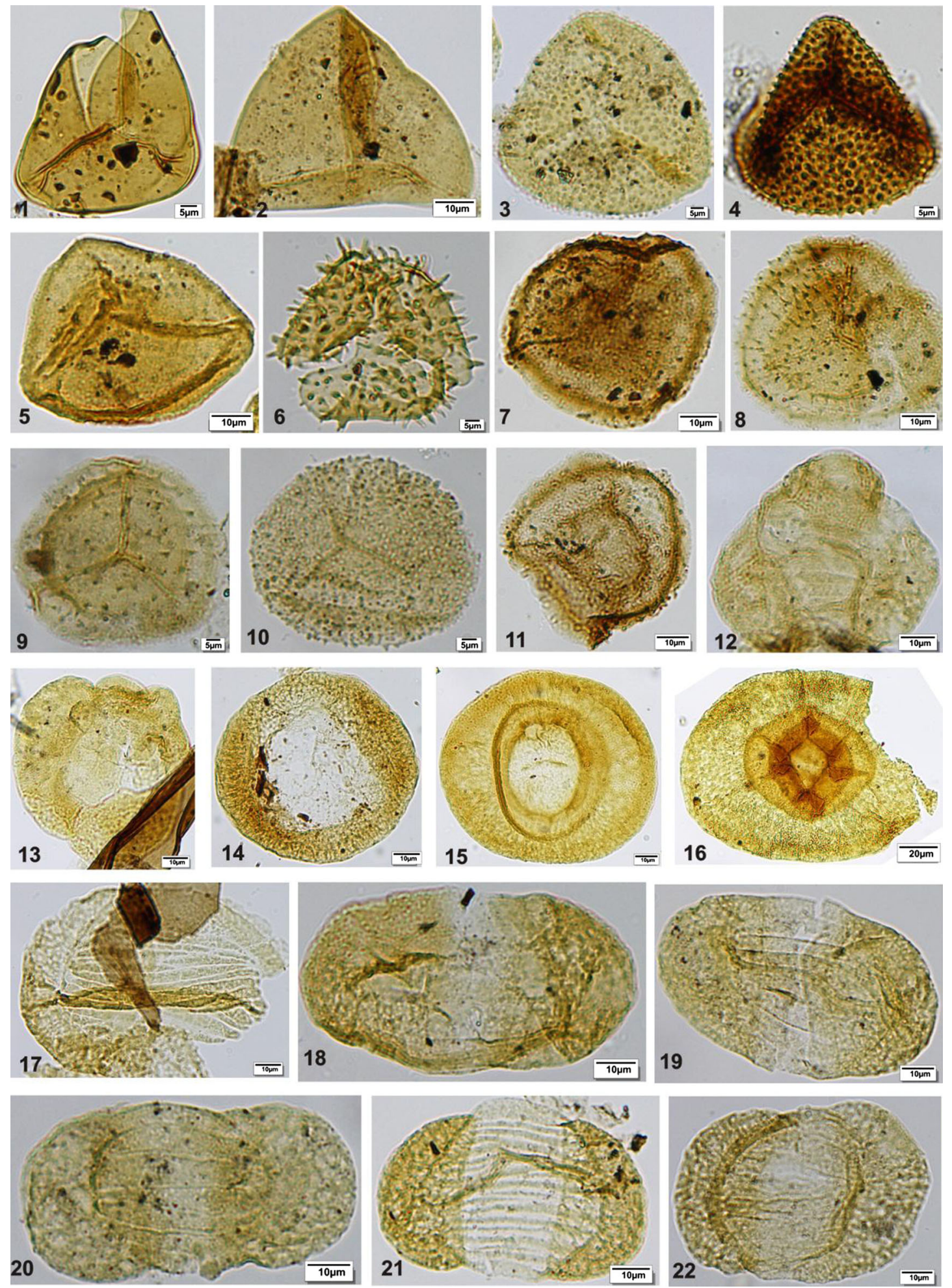

PLATE I. 1. Lacinitriletes badamensis Venkatachala and Kar emend. Tiwari and Singh (1981). 2. Microbaculispora barakarensis Tiwari emend. Tiwari and Singh (1981). 3. Microbaculispora indica Tiwari emend. Tiwari and Singh (1981). 4. Didecitriletes horridus Venkatachala and Kar emend. Tiwari and Singh (1981). 5. Microfoveolatispora foveolata Tiwari emend. Tiwari and Singh (1981). 6. Acantotriletes filiformis (Balme and Hennelly) Tiwari (1965). 7. Gondisporites raniganjensis Bharadwaj (1962). 8. Lundbladispora warti Tiwari and Rana (1981). 9. Lundbladispora raniganjensis Tiwari and Rana (1981). 10. Lundbladispora willmotti Balme emend. Playford (1965). 11. Gondisporites sp. 12. Goubinispora morondavensis (Goubin) Tiwari and Rana (1981). 13. Goubinispora indica Tiwari and Rana (1981). 14. Parasaccites obscures Tiwari (1965). 15. Potonieisporites sp. 16. Potonieisporites neglectus Potonie and Lele (1961). 17. Striomonosaccites ovatus Bharadwaj (1962). 18. Faunipollenites varius Bharadwaj emend. Tiwari et al. (1989). 19. Faunipollenites singrauliensis Sinha (1972). 20. Striatites levistriatus Bharadwaj and Tiwari (1977). 21. Striatopodocarpites magnificus Bharadwaj and Tiwari (1964). 22. Striatopodocarpites antiques (Leschik) Soritschewa and Sedova (1954). 

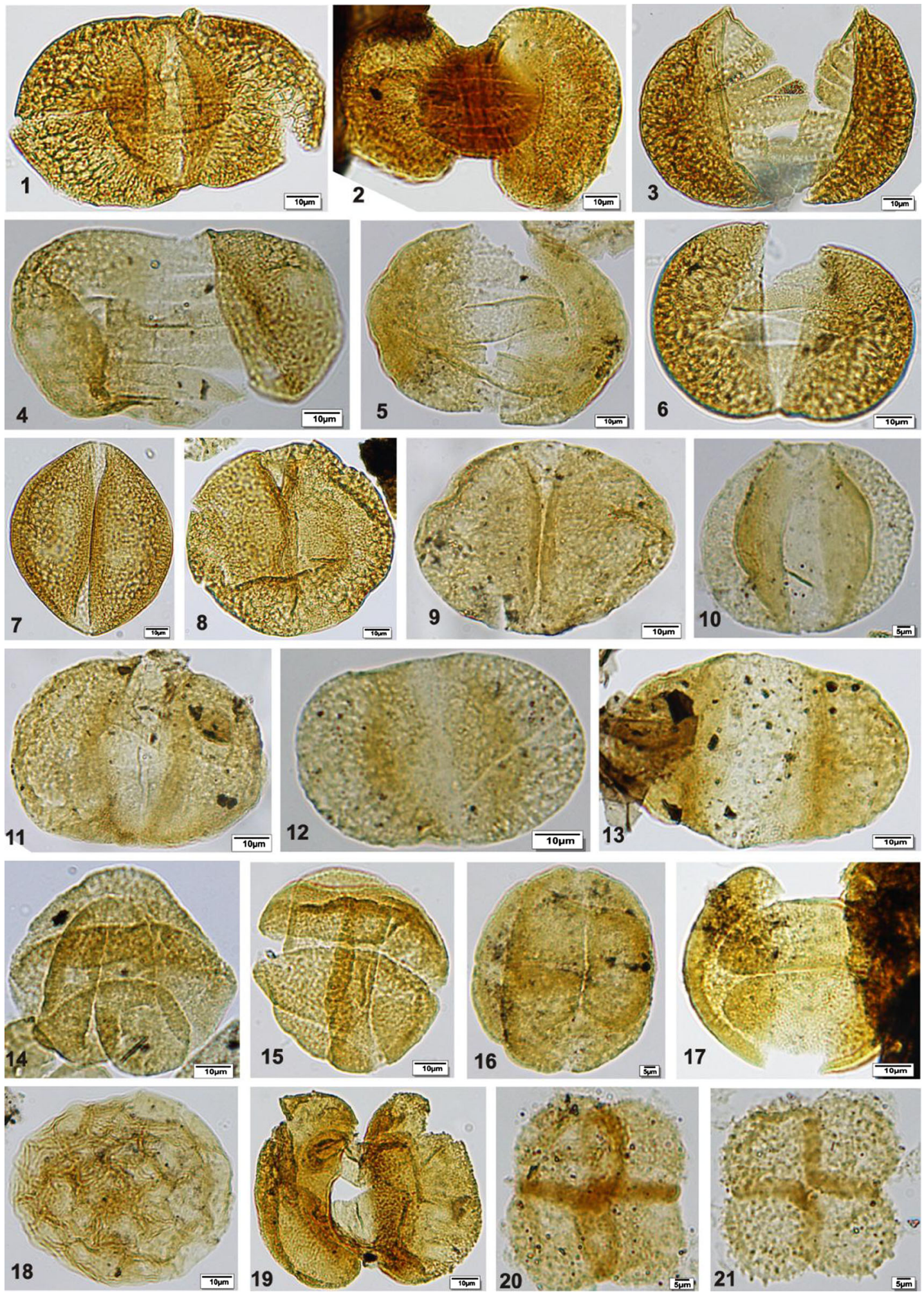

PLATE II. 1. Crescentipollenites fuscus Bharadwaj, Tiwari and Kar (1974). 2. Verticipollenites gibbosus Bharadwaj (1962). 3. Arcuatipollenites asansoliensis (Tiwari and Rana) Tiwari and Vijaya (1995). 4. Arcuatipollenites pellucidus (Goubin) Tiwari and Vijaya (1995). 5. Arcuatipollenites paliensis (Tiwari and Ram-Awatar) Tiwari and Viajaya (1995). 6. Arcuatipollenites tethysensis (Vijaya and Tiwari) Tiwari and Vijaya (1995). 7. Scheuringipollenites tentulus Tiwari ememd. Tiwari (1973). 8. Scheuringipollenites maximus (Hart) Tiwari (1973). 9. Scheuringipollenites barakarensis Tiwari ememd. Tiwari (1973). 10. Alisporites ovalis Kumar (1973). 11. Alisporites plicatus Kar et al. (1972). 12. Falcisporites zapfei Leschick emend. Klaus (1963). 13. Klausipollenites schaubergeri Potonie and Klaus emend. Jansonius (1962). 14 and 15. Guttulapollenites hannonicus Goubin (1965). 16. Guttulapollenites sp. 17. Dicappipollenites crassus (Sinha) Tiwari and Vijaya (1995). 18. Cf. Maculatisporites sp. 19. Lueckisporites virkkiae Potonie and Klaus in Leschic (1956). 20 and 21. Qudrisporites horridus Hennelly emend. Potonie and Lele (1961). 
Table 2. Details of lithofacies and spore-pollen content and composition of dispersed organic matter at different depths in Borehole MBKW-3, Mand-Raigarh Coalfield.

\begin{tabular}{|c|c|c|}
\hline Depth $(\mathrm{m})$ & Lithology & Remarks \\
\hline 41.95 & Shale & Preservation good, rich in palynomorphs and diversified, less amorphous and plant debris \\
\hline 45.90 & Shale & $\begin{array}{l}\text { Preservation bad, medium palynomorphs, exine peeled out, much plant debris-cuticle, } \\
\text { cells and wood splinters }\end{array}$ \\
\hline 66.75 & Shale & Preservation bad, rich palynomorphs, broken, granular sized amorphous present \\
\hline 79.10 & Shale & Preservation bad, very less palynomorphs, much amorphous present, less plant debris \\
\hline 98.35 & Shale & Preservation good, rich palynomorphs, less amorphous and plant debris \\
\hline 145.30 & Shale & Preservation bad, no palynomorphs, abundance of amorphous and woody splinters \\
\hline 156.19 & Shale & $\begin{array}{l}\text { Preservation bad, medium palynomorphs, broken, exine peeled out, granular sized } \\
\text { amorphous matter and less woody splinters present }\end{array}$ \\
\hline 162.10 & Shale & Preservation good, rich palynomorphs, rich dark, uneven, plant debris present \\
\hline 197.90 & Mudstone & Preservation good, rich palynomorphs, less amorphous and plant debris present \\
\hline 198.33 & $\begin{array}{l}\text { Micaceous } \\
\text { siltstone }\end{array}$ & Preservation good, rich palynomorphs, less amorphous matter present \\
\hline 213.40 & Coal & Preservation bad, rich palynomorphs, abundance of amorphous matter present \\
\hline 214.35 & Shale & $\begin{array}{l}\text { Preservation bad, less palynomorphs, full of dark to brown amorphous matter and } \\
\text { woody splinters present }\end{array}$ \\
\hline 257.23 & Coal & $\begin{array}{l}\text { Preservation bad, rich palynomorphs, broken, exine peeled out, full of amorphous } \\
\text { matter present }\end{array}$ \\
\hline 289.15 & Coal & Preservation is bad, very less palynomorphs, full of amorphous matter present \\
\hline 289.60 & Coal & $\begin{array}{l}\text { Preservation is good, medium palynomorphs, broken, exine peeled out, granular sized, } \\
\text { dark to dark brown amorphous matter present }\end{array}$ \\
\hline 300.49 & Coal & Preservation is bad, less palynomorphs, less amorphous and plant debris present \\
\hline 301.35 & Coal & Preservation is bad, less palynomorphs, broken, amorphous matter is dominance \\
\hline 306.30 & Shale & Preservation good, rich palynomorphs, less amorphous matter and plant debris present \\
\hline 308.65 & Shale & Preservation good, rich palynomorphs, less amorphous matter and plant debris present \\
\hline 315.05 & Shale & $\begin{array}{l}\text { Preservation is bad, medium palynomorphs, broken, exine peeled out, granular sized } \\
\text { amorphous matter present }\end{array}$ \\
\hline 332.81 & Coal & $\begin{array}{l}\text { Preservation is bad, less palynomorphs, granular dark plant debris overlapped and } \\
\text { woody splinter dominated }\end{array}$ \\
\hline 335.05 & Coal & Preservation is bad, less palynomorphs, broken, exine peeled out, amorphous matter present \\
\hline 336.81 & Coal & Preservation is bad, no palynomorphs, amorphous matter and woody shreds present \\
\hline 337.64 & Coal & Preservation is bad, no palynomorphs, full of amorphous matter present \\
\hline 337.72 & Shale & Preservation is good, rich in palynomorphs, less in amorphous and woody shreds \\
\hline 358.55 & Coal & Preservation is bad, less palynomorphs, granular sized, black amorphous matter abundant \\
\hline 379.74 & Coaly shale & Preservation is bad, less palynomorphs, granular sized, black amorphous matter abundant \\
\hline 381.72 & Coal & Preservation is bad, no palynomorphs, full of amorphous matter present \\
\hline 383.03 & Shale & Preservation is bad, no palynomorphs, full of amorphous matter present \\
\hline 384.73 & Shale & Preservation is bad, no palynomorphs, full of amorphous matter present \\
\hline 385.53 & Shale & Preservation is bad, no palynomorphs, full of amorphous matter and woody shreds present \\
\hline 386.73 & Coal & Preservation is bad, no palynomorphs, full of amorphous matter and woody shreds present \\
\hline 396.38 & Shale & Preservation is bad, no palynomorphs, full of dark coloured debris present \\
\hline 399.47 & Shale & Preservation is good, less palynomorphs, dark coloured dominant \\
\hline 416.15 & Shale & $\begin{array}{l}\text { Preservation is good, no palynomorphs, abundance of quadrisporites, no woody and } \\
\text { amorphous matter }\end{array}$ \\
\hline 411.93 & Shale & Full of woody shreds \\
\hline 413.05 & Shale & Preservation bad, no palynomorphs, quadrisporites dominant (distinct algae) \\
\hline 442.10 & Silty shale & Preservation good, no palynomorphs, full of plant remains \\
\hline 508.70 & Shale & Preservation good, no palynomorphs, full of plant remains \\
\hline 530.65 & Shale & Preservation good, no palynomorphs, full of plant remains \\
\hline 561.50 & Shale & Preservation good, no palynomorphs, full of plant remains \\
\hline 562.98 & Shale & Preservation is good, rich palynomorphs, small to granular, dark amorphous matter present \\
\hline 575.50 & Shale & Preservation bad, medium palynomorphs, broken, exine peeled out, less amorphous present \\
\hline 632.05 & Silty shale & Preservation is good. Less palynomorphs, broken, less dark debris present \\
\hline 633.60 & Silty shale & Preservation is good. Less palynomorphs, broken, less dark debris present \\
\hline 637.50 & Coal & Preservation is good. Less palynomorphs, broken, less dark debris present \\
\hline 638.75 & Coal & Full of woody shreds \\
\hline 640.00 & Coaly shale & Full of woody shreds \\
\hline 641.00 & Shale & Preservation is good. Less palynomorphs, broken, less dark debris present \\
\hline 643.84 & Shale & Preservation is good. Less palynomorphs, broken, less dark debris present \\
\hline
\end{tabular}


Table 3. Composition of palynoassemblages identified in borehole MBKW-3, Mand-Raigarh Coalfield, Chhattisgarh.

\begin{tabular}{|c|c|c|c|c|c|}
\hline $\begin{array}{l}\text { Assemblage zone } \\
\text { identified (after } \\
\text { Tiwari and Tripathi } \\
\text { 1992) }\end{array}$ & Lithology & $\begin{array}{l}\text { Depth } \\
(\mathrm{m})\end{array}$ & Palynocomposition & $\begin{array}{l}\text { Significant age } \\
\text { marker species }\end{array}$ & Age \\
\hline $\begin{array}{l}\text { Gondisporites } \\
\text { raniganjensis }\end{array}$ & $\begin{array}{l}\text { Shale } \\
\text { and coal }\end{array}$ & $\begin{array}{r}41.95- \\
98.35\end{array}$ & $\begin{array}{l}\text { Dominance of Gondisporites spp., } \\
\text { Striatopodocarpites spp., Faunipollenites } \\
\text { spp. and fair appearance of Guttulapollenites } \\
\text { spp., Arcuatipollenites spp., } \\
\text { Lundbladisporites, Goubinispora spp., and } \\
\text { nonstriated bisaccates pollens - Alisporites } \\
\text { spp., Klausipollenites spp. Triletes are less } \\
\text { but represents Microbaculispora, } \\
\text { Microfoveolatispora. Some palynomorphs } \\
\text { less in number are Cresentipollenites, } \\
\text { Weylandites, Distriatites, Didecitriletes and } \\
\text { Scheuringipollenites }\end{array}$ & $\begin{array}{l}\text { Guttulapollenites } \\
\text { hanonicus, } \\
\text { Arcuatipollenites } \\
\text { pellucidus, } \\
\text { Goubinispora } \\
\text { indica }\end{array}$ & $\begin{array}{l}\text { Latest } \\
\text { Permian }\end{array}$ \\
\hline $\begin{array}{l}\text { Faunipollenites } \\
\text { varius }\end{array}$ & Shale & 258.8 & $\begin{array}{l}\text { Dominance of Faunipollenites spp. and } \\
\text { Scheuringipollenites spp., and subdominance } \\
\text { of Striatopodocarpites spp., and fair } \\
\text { occurrence of nonstriated bisaccate. Other } \\
\text { palynomorphs recovered are Parasaccites, } \\
\text { Striasulcites, Weylandites, Tiwariasporites } \\
\text { and Microfoevolatispora }\end{array}$ & $\begin{array}{l}\text { Faunipollenites } \\
\text { varius and } \\
\text { Scheuringipollenites } \\
\text { gondwanensis, }\end{array}$ & $\begin{array}{c}\text { Late Early } \\
\text { Permian }\end{array}$ \\
\hline $\begin{array}{l}\text { Scheuringipollenites } \\
\text { barakarensis }\end{array}$ & Coal & 289.60 & $\begin{array}{l}\text { Dominance of Scheuringipollenites spp., } \\
\text { Faunipollenites spp., and Striatopodocarpites } \\
\text { spp. Other palynomorphs recovered are } \\
\text { Crescentipollenites, Weylandites, } \\
\text { and fair occurrence of Triletes namely } \\
\text { Microbaculispora spp., Microfoevolatispora }\end{array}$ & $\begin{array}{l}\text { Faunipollenites } \\
\text { varius } \\
\text { Scheuringipollenites } \\
\text { gondwanensis and } \\
\text { Striatopodocarpites }\end{array}$ & $\begin{array}{c}\text { Late Early } \\
\text { Permian }\end{array}$ \\
\hline $\begin{array}{l}\text { Scheuringipollenites } \\
\text { barakarensis }\end{array}$ & Shale & 306.30 & $\begin{array}{l}\text { Dominance of Scheuringipollenites spp., sub- } \\
\text { dominance of Faunipollenites spp., } \\
\text { Striatopodocarpites spp., and Parasaccites. } \\
\text { Less in count but stratigraphically important } \\
\text { genus are Arcuatipollenites, Weylandites sp., } \\
\text { triletes are less but represented by } \\
\text { Microfoveolatispora, Barakarites, } \\
\text { Tiwarisporis }\end{array}$ & $\begin{array}{l}\text { Scheuringipollenites } \\
\text { gondwanensis and } \\
\text { Faunipollenites } \\
\text { varius }\end{array}$ & $\begin{array}{c}\text { Late Early } \\
\text { Permian }\end{array}$ \\
\hline \multirow[t]{4}{*}{$\begin{array}{l}\text { Scheuringipollenites } \\
\text { barakarensis }\end{array}$} & Coal & 337.72 & $\begin{array}{l}\text { Dominance of Scheuringipollenites spp., sub- } \\
\text { dominance of Faunipollenites spp., } \\
\text { Striatopodocarpites spp., and Parasaccites. } \\
\text { Less in count but stratigraphically important } \\
\text { genus are Arcuatipollenites, Weylandites sp., } \\
\text { triletes are less but represented by } \\
\text { Microbaculispora and Microfoveolatispora }\end{array}$ & $\begin{array}{l}\text { Scheuringipollenites } \\
\text { gondwanensis and } \\
\text { Faunipollenites } \\
\text { varius and } \\
\text { Arcuatipollenites } \\
\text { sp. }\end{array}$ & $\begin{array}{c}\text { Late Early } \\
\text { Permian }\end{array}$ \\
\hline & Shale & 399.47 & $\begin{array}{l}\text { Fair occurrence of Parasaccites, } \\
\text { Plicatipollenites, Sahnites, Corricasaccites, } \\
\text { Rhizomaspora, Dicappipollenites }\end{array}$ & Parasaccites & \\
\hline & Shale & 416.65 & Dominance only quadrisporites & $\begin{array}{l}\text { Qudrisporites } \\
\text { horridites }\end{array}$ & \\
\hline & & $\begin{array}{r}442.10- \\
640.00\end{array}$ & $\begin{array}{l}\text { Less occurrence of nonstriate bisaccate- } \\
\text { Scheuringipollenites and radial } \\
\text { monosaccates }\end{array}$ & $\begin{array}{l}\text { Scheuringipollenites } \\
\text { barakarensis, } \\
\text { Parasaccate spp. }\end{array}$ & \\
\hline
\end{tabular}


Table 4. Palynologic dating in Borehole MBKW-3 (41.95-640.00 m depth), Mand-Raigarh Coalfield.



taxa include Parasaccites spp. Other stratigraphically significant taxa in this assemblage are Microbaculispora indica, Micorbaculispora tentula, Microfoveolatispora foeveolata, Verticipollenites sp., Tiwariasporis gondwanensis, Rizomaspora indica, Crescentipollenites sp., and Weylandites sp.

The spore/pollen composition of palynoassemblage-III correlates with the Scheuringipollenites barakarensis palynozone of Barakar Formation, Damodar Basin, which is of Early Permian age (Tiwari and Tripathi 1988, 1992).

Strata between 358.55 and $640.00 \mathrm{~m}$ depths, which include shales, silty shales, siltstones, coaly shales, and coal, had poor spore and pollen yields (especially, Scheuringipollenites and radial monosaccates). Macerations contained an abundance of black woody splinters, plant tissues, and amorphous matter.

Palynodating: Late Early Permian (Lower Barakar Formation).

\section{Discussion}

The 598.05-m thick interval of Barakar Formation strata encountered in Borecore MBKW-3, BarpaliKarmitikra block, Mand-Raigarh Coalfield was investigated palynologically. In this litho-succession, three palynozones were identified based upon the dominance, and sub-dominance of palynotaxa, stratigraphic importance of key taxa, and their relative occurrence along with other associated significant species. Based on these palynozones, the biostratigraphic status, age and phytogeographical provincialisms of the palynoflora are discussed (table 6).

In the younger part $(41.95-98.35 \mathrm{~m})$ of the borecore, abundant striate bisaccate pollen taxa with zonate spores, such as Gondisporites (79.10$98.35 \mathrm{~m}$ depth) are common. These elements indicate a younger age for this part of the borecore than that of the Barakar Formation. The introduction of Arcuatipollenites pellucidus, A. ovatus, Guttulapollenites hannonicus, and Lundbladispora microconata at 41.95, 45.90, $98.35 \mathrm{~m}$, and Alisporites opii, Klausipollenites sp., and Goubinispora indica at $41.95 \mathrm{~m}$, indicate the closing phase of Permian, as presence of these key species mark a transition from Permian to the Lower Triassic.

The strata at $135.55-284.89 \mathrm{~m}$ had yielded very low spore and pollen grain and abundant woody and amorphous organic matters (table 2). Variants of striate and nonstriate bisaccate pollen taxa within this $149.34 \mathrm{~m}$ are placed in the Faunipollenites and Scheuringipollenites palynozones. This association correlates with the Barakar Formation 
Table 5. List of the palynomorph taxa identified in present study, arranged under probable plant groups.

\section{Palynotaxa}

Sphenopsida

Laevigatosporites Ibrahim (1933)

Laevigatosporites vulgaris Balme and Hennelly (1956)

Lycopsida

Indotriradites Tiwari (1964)

Indotriradites sparsus Tiwari (1965)

Gondisporites Bharadwaj (1962)

Gondisporites reticulatus Tiwari and Ram-Awtar (1989)

Gondisporites raniganjensis Bharadwaj (1962)

Filicopsida

Brevitriletes Bharadwaj and Srivastava (1969)

Brevitriletes unicus Bharadwaj and Srivastava (1969)

Cyclogranisporites Potonié and Kremp (1954)

Cyclogranisporites gondwanensis Bharadwaj and Salujha (1964)

Cyclogranisporites sbarakarensis Srivastava (1970)

Didecitriletes Venkatachala and Kar (1965)

Didecitriletes horridus Venkatachala and Kar (1965)

Horriditriletes Bharadwaj (1962)

Horriditriletes curvibaculosus Bharadwaj and Salujha (1964)

Horriditriletes sp.

Microbaculispora indicus Bharadwaj (1962)

Microbaculispora gondwanensis Bharadwaj (1962)

Microbaculispora barakarensis Tiwari (1965)

Microbaculispora indica (Tiwari) emend. Tiwari and Singh (1981)

Microbaculispora tentula Tiwari (1965)

Microfoveolatispora Bharadwaj (1962)

Microfoveolatispora bokaroensis Tiwari (1965)

Microfoveolatispora foveolata Tiwari (1965)

Gymnosperms

Praecolpatites Bharadwaj and Srivastava (1969)

Praecolpatites sp.

Tiwariasporis Maheshwari and Kar (1967)

Tiwariasporis flavatus Maheshwari and Kar (1967)

T. gondwanensis (Tiwari) Maheswari and Kar (1967)

Weylandites Bharadwaj and Srivastava (1969)

Weylandites circularis Bharadwaj and Srivastava (1969)

Weylandites indicus Bharadwaj and Srivastava (1969)

Coniferopsida

Monosaccate

Barakarites Bharadwaj and Tiwari (1964)

Barakarites indicus Bharadwaj and Tiwari (1964)

Barakarites indica Tiwari (1965)

Distriamonosaccites Bharadwaj (1962)

Distriamonosaccites ovalis Bharadwaj and Salujha (1964)

Parasaccites Bharadwaj and Tiwari (1964)

Parasaccites bilateralis Tiwari (1965)

Parasaccites korbaensis Bharadwaj and Tiwari (1964)

Parasaccites obscurus Tiwari (1965)

Plicatipollenites Lele (1964)

Plicatipollenites gondwanensis (Balme and Hennely) Lele (1964)

Striamonosaccites Bharadwaj (1962)

Striamonosaccites circularis Bharadwaj and Salujha (1964)

Striomonosaccites ovatus Bharadwaj (1962) 
Table 5. (Continued.)

\section{Palynotaxa}

Goubinispora Tiwari and Rana (1981)

Goubinispora indica Tiwari and Rana (1981)

Goubinispora triassica Vijaya and Tripathi (2008)

Goubinispora sp.

Nonstriate bisaccate

Krempipollenites Tiwari and Vijaya (1995)

Krempipollenites indicus Tiwari and Vijaya (1995)

Alisporites Daugherty emend. Jansonius (1971)

Alisporites opii Daugherty (1971)

Alisporites damudicus Tiwari and Rana (1981)

Satsangisaccites Bharadwaj and Srivastava (1969)

Satsangisaccites nidpurensis Bharadwaj and Srivastava (1969)

Klausipollenites Jansoius (1962)

Klausipollenites schaubergeri Potonie and Klaus emend Jansonius (1962)

Falcisporites Leschik emend. Klaus (1963)

Falcisporites sp.

Platysaccus Naumova emend. Potonié and Klaus (1954)

Platysaccus densus Kar (1968)

Scheuringipollenites Tiwari (1973)

Scheuringipollenites tentulus (Tiwari) Tiwari (1973)

Scheuringipollenites maximus (Hart) Tiwari (1973)

Scheuringipollenites barakarensis (Tiwa) Tiwari (1973)

Scheuringipollenites triassicus (Bharadwaj and Srivastava) Tiwari (1973)

Striate bisaccate

Crescentipollenites Bhardwaj, Tiwari and Kar (1974)

Crescentipollenites fuscus (Baradwaj) Bhardwaj, Tiwari and Kar (1974)

Crescentipollenites. Gondwanensis (Mahesh) Bharadwaj et al. (1974)

Distriatites Bharadwaj (1962)

Distriatites bilateris Bharadwaj (1962)

Faunipollenites Bharadwaj (1962)

Faunipollenites varius Bharadwaj (1962)

Faunipollenites singrauliensis Sinhas (1972)

Faunipollenites perexiguus Bharadwaj emend, Tiwari et al. (1989)

Rhizomaspora Wilson (1962)

Rhizomaspora indica Tiwari (1965)

Striasulcites Venkatachala and Kar (1968)

Striasulcites tectus Venkatachala and Kar (1968)

Striasulcites ovatus Venkatachala and Kar (1968)

Striatites Pant emend. Bharadwaj (1962)

Satriatites communis Bharadwaj and Salujha (1964)

Satriatites communis Bharadwaj and Salujha (1964)

Striatites tectus Venkatachala and Kar (1968)

Striatopodocarpites Soritsch and Sedova emend. Bharadwaj (1962)

Striatopodocarpites ovatus (Maheshwari) Bharadwaj and Dwivedi (1981)

Striatopodocarpites magnjficus Bharadwaj and Salujha (1964)

Verticipollenites Bharadwaj (1962)

Verticipollenites oblongus Bharadwaj (1962)

Taeniate Bisaccate

Arcuatipollenites Tiwari and Vijaya (1995)

Arcuatipollenites pellucidus (Goubin) Tiwari and Vijaya (1995)

Arcuatipollenites paliensis (Tiwari and Ram-Awatar) Tiwari and Vijaya (1995)

Arcuatipollenites ovatus (Goubin) Tiwari and Vijaya (1995)

Arcuatipollenites sp.

Guttulapollenites Goubin (1965)

Guttulapollenites hannonicus Goubin (1965)

Guttulapollenite punctatus Venkatachala, Goubin and Kar

Dicappipollenites Tiwari and Vijaya (1995)

Dicappipollenites crassus (Sinha) Tiwari and Vijaya (1995)

Dicappipollenites singrauliensis (Sinha) Tiwari and Vijaya (1995) 
Table 6. Distribution of stratigraphically significant and geographically restricted palynotaxa during Late Permian time within the Guttulapollenites showing palaeophytogeograhic province in the central part of Gondwana.

\begin{tabular}{|c|c|c|c|}
\hline Sl. no. & Basin/area & Formation & References \\
\hline \multicolumn{4}{|l|}{ India } \\
\hline 1 & Satpura & Bijori & Bharadwaj et al. (1978) \\
\hline 2 & Godavari & Kamptee (Raniganj) & Jha and Srivastava (1996) \\
\hline 3 & South Rewa & Pali Formation (Middle Pali) & Ram-Awatar (1996) \\
\hline 4 & Wardha Valley & Kamthi (Late Permian) & Bhattacharya (2004) \\
\hline \multicolumn{4}{|c|}{ Pakistan } \\
\hline 1 & Salt Range & Upper Chidru & Balme (1970) \\
\hline \multicolumn{4}{|c|}{ Antarctica } \\
\hline 1 & Amery Basin & Upper Chidru & Balme (1970) \\
\hline 2 & Bainmedart Coal Measures & Late Permian & Balme and Palyford (1967) \\
\hline \multicolumn{4}{|c|}{ Madagascar } \\
\hline 1 & Lr. Sakamena Group & Late Permian/E. Triassic & Goubin (1965) \\
\hline \multicolumn{4}{|c|}{ South Africa } \\
\hline 1 & Upper Karoo Sequence & Late Permian & Anderson (1977) \\
\hline 2 & Tanzanian & Late Permian & $\begin{array}{l}\text { Hankel (1987); Msaky and Srivastava } \\
(1997) \text {; Wescott et al. (1999); Weiss in } \\
\text { Wopfner and Kayya (1999) }\end{array}$ \\
\hline 3 & Zimbabwae & Late Permian & Falcon (1975); Osterian and Millstead (1994) \\
\hline 4 & Zambia & Late Permian & Utting (1979) \\
\hline
\end{tabular}

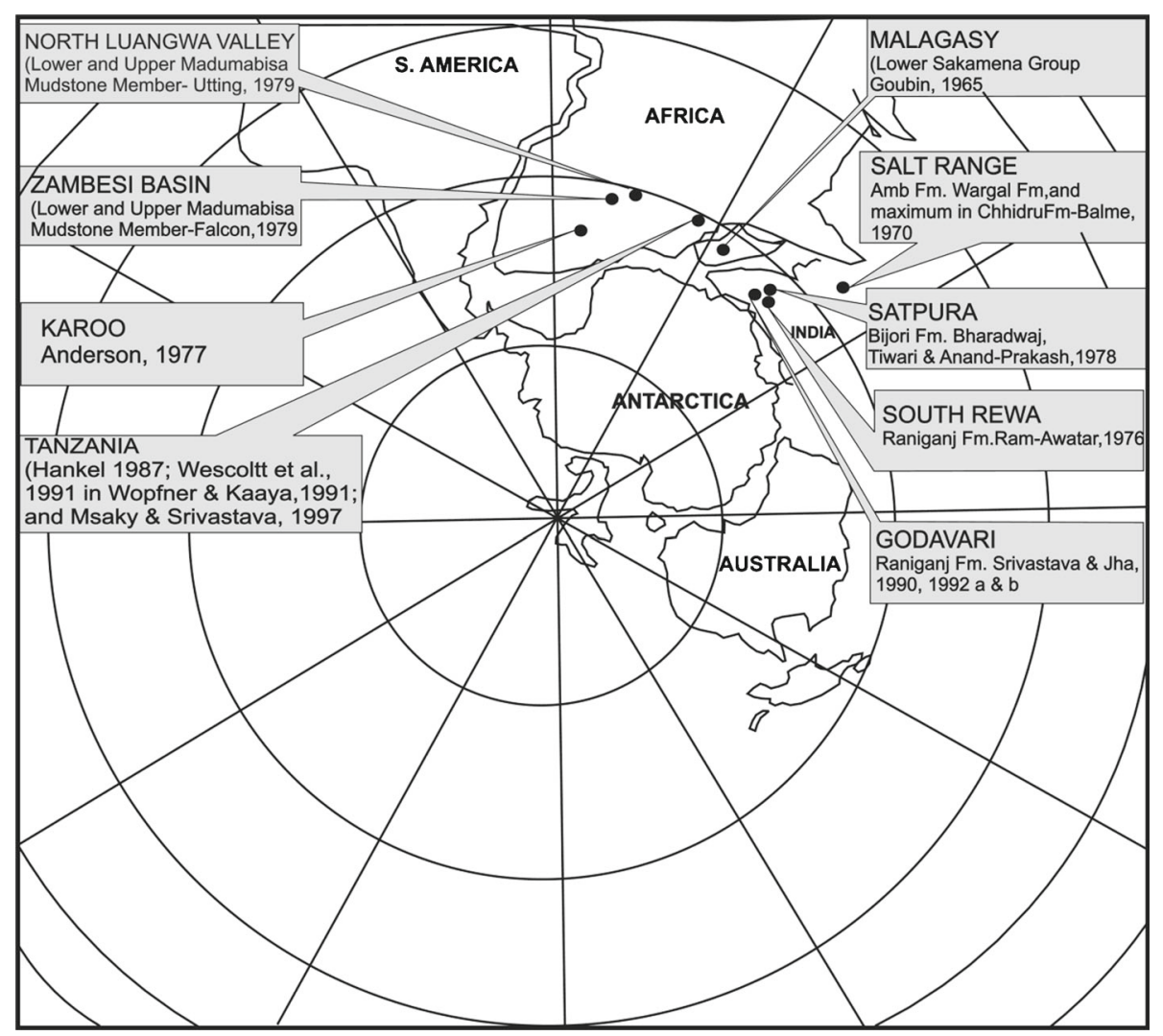

Figure 4. Distribution of stratigraphically significant and geographically restricted palynotaxa during Late Permian time in the Guttulapollenites palaeophytogeographic province (after Jha 2006). 
of the Damodar Basin, which is late Early Permian in age (Tiwari and Tripathi 1992).

The lower part of the core between 287.15 and $640.00 \mathrm{~m}$ yielded predominantly nonstriate bisaccate Scheuringipollenites and striate bisaccate Faunipollenites. Based on the abundance of these pollen taxa this interval is placed in the Scheuringipollenites-Faunipollenites palynozone and is comparable with the Lower Barakar Formation of Damodar Basin of late Early Permian age (Tiwari and Tripathi 1992). In general, the specimens are poorly preserved with an abundance of vegetal matter and dark broken wood debris (table 2).

The cyclic sequence of siltstones, mudstones, shales, coaly shales, and coal facies of the Barakar Formation (41.95-640.00 m) is not consistently productive palynologically. Previously, this lithosuccession was considered to be Early Permian in age (GSI, table 1 and figure 2).

The infrequent occurrence of Scheuringipollenites, Faunipollenites, Striatopodocarpites and radial monosaccates, along with abundance of plant remains and amorphous matter between 358.55 and $640.00 \mathrm{~m}$ is indicative of the Barakar Formation.

\section{Phytogeographic provincialism}

It is well documented that the palynotaxa Guttulapollenites is known from most, if not all, of the Gondwana continents (India, Australia, Madagascar, Africa, Antarctica and Salt Range). In the Assemblage Zone-I (Gondisporites ranigangensis), a large number of striate bisaccate and taeniate pollen were recorded in association with Guttulapollenites. This genus was first reported by Goubin (1965), and later emended by Venkatachala et al. (1967). To date, only two species are known; Guttulapollenites hannonicus and G. gondwanensis were recorded by Goubin (1965). In addition, Guttulapollenites is known from all the Gondwanan continents (table 6, figure 4).

Outside former Gondwanaland, Guttulapollenites has also been recorded from the Triassic sediments in the Netherlands by Visscher (1966). The occurrence of Guttulapollenites in the Netherlands may be due to migration along the southern Tethys coast into Europe (Bharadwaj 1976).

It is generally believed that two phytogeographic provinces: an Africa/West Gondwanaland and an Australia/East Gondwanaland existed (Truswell 1980). Within the accepted model of the supercontinent Gondwanaland, it is opined that it contained two segments; the west Gondwanaland province that includes Africa and South America and the east Gondwanaland province consisting
Antractica, Australia and India. Recently, Jha (2006) suggested based on palynology that there were three palaeophytogeographical provinces during Late Permian period. They are the East Gondwana Floral Province (Australia and part of Antractica, N-E part of India, viz., Arunachal Pradesh); West Gondwana Floral Province (South America and western half of Africa); and Central Gondwana Floral Province (Antarctica, southern part of Africa, Madagascar, India and Pakistan (figure 4)).

During the Late Permian time, India and southeastern Africa (Kenya, Tanzania, Zimbabwe and South Africa) were located in the same latitudinal position, approximately $40^{\circ}-60^{\circ}$ south of the equator (Bharadwaj 1976). It is possible that during Permian time both continents (India and Africa) were connected, which has been suggested by an earlier study (Medlicot and Blanford 1879). On the Gondwana supercontinent Guttulapollenites is the only taxon that has been recorded from India, Pakistan (Salt Range), Malagasy, Africa and Antarctica constituting a distinct phytogeographic province. The occurrence of abundant Guttulapollenites from the Mand-Raigarh Coalfield indicates that same phytogeographic province existed in India and South Africa.

\section{Conclusions}

- Three palynoassemblages have been identified from borecore MBKW-3 in the Mand-Raigarh Coalfield and are indicative of Early to Late Permian age.

- The Raniganj Formation was intersected between 41.95 and $98.35 \mathrm{~m}$ depth. The Lower Barakar and Upper Barakar Formation were identified between 135.55-284.89 and 287.15-640 $\mathrm{m}$, respectively.

- The occurrence of abundant Guttulapollenites in the assemblages, attests to the existence of phytogeographic provincialism in the Gondwana supercontinent.

\section{Acknowledgements}

Authors are thankful to Prof. Sunil Bajpai, Director, BSIP, Lucknow for kind permission to publish this work. They extend their sincere thanks to the Dy. DG and officers of the Coal Wing Division, Geological Survey of India, Kolkata, for providing borecore samples for the present study. They also extend sincere thanks to reviewer Dr Cortland Eble, Kentucky Geological Survey, University of Kentucky for encouragement, suggestions and comments, which have greatly improved the 
earlier version of the manuscript. One of the authors (Saurabh Gautam) expresses his gratitude to the UGC, New Delhi for granting the RGNF Fellowship to carry out Ph.D. work at BSIP, Lucknow.

\section{References}

Bharadwaj D C 1976 Palaeogeograhy of India during Gondwana time and its bearing on the climate; Geophytology 6 153-161.

Chakraborti B 2001 New palaeobotanical evidence for Early Triassic to Middle Triassic age for the lower most red bed of Kampthi Formation, Raigarh Gondwana Basin, M.P; In: Proc. Natl. Sem. on Recent Advances in Coal and Lignite Basins of India, Calcutta 1997 (eds) Dutta et al., Geol. Surv. India Spec. Publ. 54 113-122.

Chakraborti B and Chakraborty S 2001 Triassic floral assemblage from Baronakunda, Raigarh Gondwana basin, Madhya Pradesh; In: Proc. Natl. Sem. on Recent Advances in Geology of Coal and Lignite Basins of India; Geol. Surv. India. Spec. Publ. 54 103-112.

Chakraborti B and Ram-Awatar 2006 Inter-relationship of the palynofloral assemblages from Mand Coalfield, Chhattisgarh and its significance; Indian Minerals 60(3\&4) $153-170$.

Chakraborti B, Roy D K, Rajaram K N and Mukhopadhyay G C 2002 Final report on regional exploration for coal in Ongana-Potiya area, Mand Coalfield, Raigarh District, Chhattisgarh; Unpubl. Rep. Geol. Surv. India, Coal Wing.

Goubin N 1965 Description et repartition des principaux pollenites permicns, triassiques et jurassiques des sondages du basin de Morondava (Madagascar); Revue Institut Francais du Petrole 20 1415-1461.
Jana B N, Bhattachryya A P and Chakraborti B 2002 Permian palynological succession from Mand-Raigarh Coalfield, Chhattisgarh; J. Geol. Soc. India 59 537546.

Jha Neerja 2006 Permian palynology from India and AfricaA phytogeographical paradigm; J. Palaeontol. Soc. India 51(1) $43-55$.

Medlicot H B and Blanford W T 1879 A manual of geology of India; Geol. Surv. India 1 1-144.

Raja Rao C S 1983 Coal resources of Madhya Pradesh, Jammu and Kashmir Coalfields of India, Mand-Raigarh Coalfield, Madhya Pradesh; Bull. Geol. Surv. India 45(3) 12-20.

Ram-Awatar 2007 Palynostratigraphy and depositional environment of Lower Gondwana sediments in Raigarh Basin, Chhattisgarh, India; In: Micropalaeontology: Application in Stratigraphy and Palaeoceanography (ed.) Devesh K Sinha, pp. 71-79.

Tiwari R S and Tripathi A 1988 Palynological zones and their climatic inference in the coal bearing Gondwana of peninsular India; Palaeobotanist 36 87-101.

Tiwari R S and Tripathi A 1992 Marker assemblage zones of spore and pollen species through Gondwana Palaeozoic and Mesozoic sequence in India; Palaeobotanist 40 194-236.

Truswell E M 1980 Permo-Carboniferous palynology of Gondwanaland: Progress and problem in the decade to 1980; BMR J. Geol. Geophys. 5 95-111.

Venkatachala B S, Goubin N and Kar R K 1967 Morphological study of Guttulapollenites Goubin; Pollen Spores 9(2) 357-362.

Vijaya and Tiwari R S 1987 Role of spore pollen species in identification of Permo-Triassic boundary in Raniganj Coalfield, West Bengal; Palaeobotanist 35 242-248.

Visscher H 1966 Palaeobotony of the mesophytic. III. Plant micofossils from the upper Bunter of Hengeol, The Netherlands; Acta Botanica Neerlandica 15 316-375. 